Original Articles

\title{
Prognostic Significance of NRAS Gene Mutations in Children with Acute Myelogenous Leukemia
}

Rabab M. Aly ${ }^{1}$, Mohamed R. El-sharnoby ${ }^{2}$ and Adel A. Hagag ${ }^{2}$

${ }^{1}$ Clinical Pathology Department, Faculty of Medicine, Mansoura University, Egypt.

${ }^{2}$ Pediatrics Department, Faculty of Medicine, Tanta University, Egypt.

Correspondence to: Rabab M. Aly, MD. Lecturer of Clinical Pathology, Faculty of Medicine, Mansoura University, Egypt. E-mail: rababzeadah@yahoo.com

Competing interests: The authors have declared that no competing interests exist.

Published: November 28, 2011

Received: July 16, 2011

Accepted: October 21, 2011

Mediterr J Hematol Infect Dis 2011, 3(1): e2011059, DOI 10.4084/MJHID.2011.055

This article is available from: http://www.mjhid.org/article/view/8841

This is an Open Access article distributed under the terms of the Creative Commons Attribution License (http://creativecommons.org/licenses/by/2.0), which permits unrestricted use, distribution, and reproduction in any medium, provided the original work is properly cited.

Abstract. Background: NRAS mutations are the most commonly detected molecular abnormalities in hematologic malignancies, especially in those of myeloid origin.

Objective: We aimed to determine the frequency of NRAS (NRAS ${ }^{\text {mutant }}$ ) mutation; and its prognostic significance in Egyptian children with acute myelogenous leukemia (AML).

Subject and methods: Peripheral blood and bone marrow (BM) samples were taken from 39 de novo pediatric AML patients. Twenty subjects with matched age and sex were selected as a control group. Samples from patients and control were analyzed for Exons 1, 2 of NRAS gene using genomic PCR-SSCP method.

Results: NRAS mutations at the time of diagnosis was found in 6/39 (15.4\%) AML cases. Patients with NRAS ${ }^{\text {mutant }}$ had no significant improved clinical outcome than patients without mutation. Patients with NRAS ${ }^{\text {mutant }}$ had similar complete remission (CR) rates compared with non-mutated patients $(66.7 \%$ vs. $69.5 \%, P=0.43)$. Those in $C R$ had a similar relapse rate regardless of the presence of NRAS ${ }^{\text {mutant }}$ (RR 33.4\% vs. 30.2\%, $\mathrm{P}=\mathbf{0 . 2 6}$ ). However, an adverse prognosis for 3 year overall survival (OS) was associated with the presence of NRAS mutations. This adverse prognosis associated with NRAS mutations was also observed in terms of disease-free survival (DFS) $(P=0.007)$. Univariate analysis showed that unfavorable prognostic factors for DFS were cytogenetic data $(P=0.005)$ and the NRAS gene mutation $(P=0.002)$.

Conclusion: NRAS ${ }^{\text {mutant }}$ did not contribute to increase the disease recurrence, however NRAS ${ }^{\text {mutant }}$ was found to be a poor prognostic factor for children with AML. Further studies to confirm these findings are required because of the small number of patients with NRAS mutation.

Introduction. Acute myeloid leukemia (AML) is characterized by expansion of myeloid blasts with suppression of normal hematopoiesis. Cytogenetic and molecular studies have defined AML as a 
heterogeneous disease. ${ }^{1}$ The presence of defined karyotypes is among the most important prognostic factors in acute myeloid leukemia (AML). However, even within defined cytogenetic groups stability of remission and long-term survival may vary significantly. Therefore, additional recurrent aberrations may have a prognostic impact. ${ }^{2}$ It has been showed that Pediatric AML patients may harbor more than one mutation at diagnosis, some of which with a possible prognostic impact. ${ }^{3-7}$ Mutations in the NRAS gene are one of these genetic aberrations that play a role in myeloid neoplasia. ${ }^{8}$

NRAS gene plays an important role in the regulatory processes that govern proliferation, differentiation and apoptosis; ${ }^{9}$ abnormality in this gene has been implicated in the pathogenesis of AML. RAS oncogenes encode a family of membrane-associated proteins, which regulate signal transduction upon binding to a variety of membrane receptors. ${ }^{10}$ There are three functional RAS genes (NRAS, KRAS and HRAS); in AML. K-RAS mutation occurs to a lower but still significant frequence in pediatric AML. ${ }^{11}$ NRAS is the most prominent; reported in $11 \%-30 \%$ of patients. ${ }^{12}$ All homologs were exclusively in codons 12,13 , and 61 conferring constitutive activation of the RAS protein, which is subsequently held in the GTP bound status leading to an increased activity of the RAS pathway causing an increased proliferation and a decreased apoptosis rate. ${ }^{13}$ RAS mutations were described in the various solid tumors as well as in hematologic malignancies. The prognostic impact of NRAS mutations is still under research and seems to vary from disease to disease,${ }^{14}$ several studies indicated a poor prognostic impact for that mutation, ${ }^{14,15}$ and however Lapillonne et al confirmed this finding in pediatric AML. ${ }^{16}$ On the contrary, Neubauer et al found a favorable outcome for malignancies with NRAS mutations, ${ }^{12}$ and some studies failed to define any prognostic impact for NRAS mutations..$^{10,13,17}$

We undertook this study to determine the frequency of NRAS mutation and its prognostic significance in a number of Egyptian pediatric patients with AML.

Patients and Methods. Newly diagnosed pediatric AML patients were included in this study; cases were recruited from pediatric hematology clinics of Tanta University Hospitals, Tanta, Egypt. Peripheral blood and BM samples were obtained from 39 de novo AML cases at initial diagnosis obtaining an informed consent from patients or their guardians; they were 21 boys and 18 girls. The median age was 7.4 years (range, 5.6-13 years). The median percentage of blasts in the fresh bone marrow samples was $(65 \%)$. All included patients were receiving the same treatment protocol approved by the Oncology Team of Tanta University Hospital
TUH; in brief they received 1-2 cycles of 14-21 days of intensively timed induction chemotherapy (doxorubicin, Ara-C, 6-thioguanine and methotrexate) depending upon $\mathrm{BM}$ aspiration done at the end of each induction course. Additional consolidation regimens included 1-2 cycles of 12-days (doxorubicin, Ara-C, VP-16 and methotrexate). Then patients who did not achieve remission received intermittent chemotherapy (Ara-C, 6-thioguanine and methotrexate) every 3 months for 6 cycles with the standard follow-up care and regular BM aspiration every 21 days to confirm remission; complete remission means normocellular bone marrow contain less than 5\% blast cells and showing evidence of normal maturation of other bone marrow elements as evidenced by the repeated BM aspiration. The average duration of follow up was mean $\pm \mathrm{SD}(32 \pm 2.24$ months $)$.

Patients were classified according to the standard methods; morphological according FAB classification, cytochemical and immunological evaluation. ${ }^{13}$ Informed consent was obtained from twenty subjects with matched age and sex who were selected as a control group. Samples from patients and control were analyzed for mutation in Exons 1, 2 of the NRAS gene using genomic PCR method.

Cytogenetic Analysis. Cytogenetic investigations were performed by karyotyping G-banding analysis in all patients. ${ }^{18}$

PCR of NRAS Gene. Genomic DNA was extracted from diagnostic bone marrow specimens of patients and control using the QIAamp DNA blood mini kit for DNA extraction provided by QIAGEN (Inc Chasworthy, CA). The concentration of extracted DNA was then measured by UV spectrophotometry at 260 \& $280 \mathrm{~nm}$ and analyzed by electrophoresis on $2 \%$ agarose gel for detection of purity.

Separate assays were developed for mutation detection at (hot spots) in codons 12/13 (exon 1) and codon 61 (exon 2). Oligonucleotide primers amplifying short fragments $\{241$ base pair (bp) for exon 1 and $201 \mathrm{bp}$ for exon 2$\}$ were designed for PCR as follows:

N12/13 assay. forward, 5'GACTGAGTACAAACTGGTGG-3'; and reverse, 5'TGCATAACTGAATGTATACCC-3'.

N61 assay. forward, 5' CAAGTGGTTATAGATGGTGAAACC-3'; and reverse,

AAGATCATCCTTTCAGAGAAAATAAT-3'.

PCR amplification was performed in 50 ul reaction, contained 50-100 ng of genomic DNA, $10 \mathrm{mM}$ Tris $\mathrm{HCl}(\mathrm{pH} 8.3), 50 \mathrm{mM} \mathrm{KCl}$ and $1.5 \mathrm{mM} \mathrm{Mg} \mathrm{Cl} 2,200$ $\mathrm{uM}$ of each deoxyribonucleotide triphosphate (dNTP), 2.5 units Taq polymerase, and 6\% dimethylsulphoxide. 
PCR conditions were as follows: (1) Exon 1, HotStarTaq (Qiagen, Valencia, CA), and $0.625 \mathrm{U}$. Primers (12.5 pmol), N12/13 forward, N12/13 reverse. Denaturing, $95 \mathrm{C}$ for 15 minutes and $94^{\circ} \mathrm{C}$ for 30 seconds; annealing, $55.5^{\circ} \mathrm{C}$ for 1 minute; extension, $72^{\circ} \mathrm{C}$ for 1 minute for 35 cycles; final cycle at $72^{\circ} \mathrm{C}$ for 10 minutes. (2) Exon 2, HotStarTaq (Qiagen), 0.625 U. Primers $(12.5 \mathrm{pmol}), \mathrm{N} 61 \mathrm{~F}$ forward, N61R reverse. Denaturing, $95^{\circ} \mathrm{C}$ for 15 minutes; $94^{\circ} \mathrm{C}$ for 30 seconds; annealing, $55.5^{\circ} \mathrm{C}$ for 1 minute; extension, $72^{\circ} \mathrm{C}$ for 1 minute for 35 cycles; final cycle at $72^{\circ} \mathrm{C}$ for 10 minutes.

Single-strand conformation polymorphism (SSCP) was performed to PCR product to detect mutations. Products were mixed with 10 volumes of loading buffer, quenched on ice immediately, and applied to $5 \%$ polyacrylamide gel electrophoresis at $50 \mathrm{~V}$, overnight, stained by silver nitrates and wrapped in plastic foil. Normal gene exhibits a specific conformational pattern, while mutant gene displays pattern with different electrophoretic mobility (mobility shift) which was confirmed by repeated SSCP (Figure 1).

Statistical Methods. Data were processed and analyzed using SPSS for windows version 16.0 (SPSS, Inc, Chicago, IL, USA). Qualitative data were expressed as frequency and percentage and quantitative data were expressed as median. Chi-square test was used for comparative analysis. The prevalence of NRAS mutations in AML was too low to permit statistical analysis for correlation with survival. Kaplan-Meier analysis was used for survival of patients. The prognostic significance of the clinical variables was assessed using the Cox proportional hazards model. For all analyses, the $P$ values were twotailed, and a $P$ value of less than 0.05 was considered statistically significant.

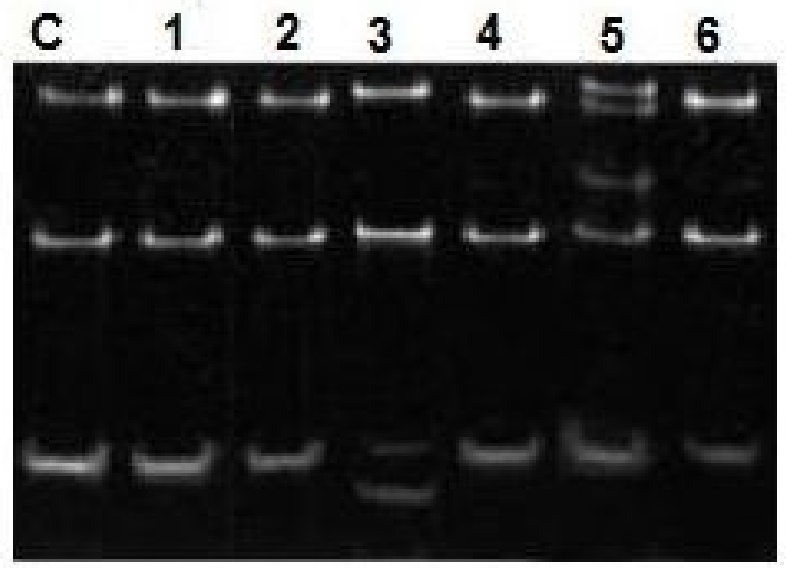

Figure 1. SSCP of PCR products from NRAS exon 1. C, normal marrow control, 1-6, samples from different pediatric patients. High molecular weight bands in lines 3 and 5 represent a normal NRAS band and a mutant band. Lines 1, 2, 4 and 6 represent wild type NRAS.
Table 1. NRAS mutations and clinical characteristics in pediatric AML cases

\begin{tabular}{|l|c|c|c|}
\hline & $\begin{array}{c}\text { No RAS } \\
\text { mutation }(\mathbf{n}=\mathbf{3 3})\end{array}$ & $\begin{array}{c}\text { RAS mutation } \\
(\mathbf{n = 6})\end{array}$ & P \\
\hline Age(median) & 6,5 & 9,5 & 0,82 \\
\hline $\begin{array}{l}\text { Leukocyte } \times 10^{3} / \mu \mathrm{L} \\
\text { (median) }\end{array}$ & 40,1 & 42,5 & 0,92 \\
\hline $\begin{array}{l}\text { Bone marrow } \\
\text { blast\%(median) }\end{array}$ & 70,2 & 58 & 0,04 \\
\hline $\begin{array}{l}\text { Peripheral blast\% } \\
\text { (median) }\end{array}$ & 55,4 & 34 & 0,01 \\
\hline
\end{tabular}

Results. Mutant band in addition to wild bands were found in $6(15.4 \%)$ of 39 pediatric AML patients, whereas 33 had only the NRAS wild-type allele $\left(\right.$ NRAS $\left.^{\text {wild }}\right)$. No apparent clinical or biologic characteristics were significantly different for the patients with NRAS gene mutations when compared with those without NRAS mutations except that there was lower peripheral and bone marrow blast $(\mathrm{P}=0.01$, $\mathrm{P}=0.04)$ in patients with NRAS mutation when compared with those without mutation (Table 1).

Patients were assigned to the following cytogenetic groups: $\mathrm{t}(8 ; 21)(15.4 \% ; 6 / 39)$, inv(16) $(15.4 \% 6 / 39)$,del $5(5.1 \% ; 2 / 39)$, del $7(2.6 \% ; 1 / 39)$; and with CN-AML $(53.8 \% ; 21 / 39)$. In $7.7 \%(3 / 39)$ of the cases, conventional karyotyping was not available (Table 2). Patients with $\operatorname{Inv}(16)$ is presented with highest WBC count(median $\left.41 \times 10^{3} / \mu \mathrm{L}\right)$, and $\mathrm{t}(8 ; 21) \mathrm{AML}$ patients with lowest WBCs (median $18 \times 10^{3} / \mu \mathrm{L}$ ) compared with the other cytogenetic groups (Table 2). The median ages of children with Inv (16) AML (7 years), with $\mathrm{t}(8 ; 21)$ (8.3 years), with $\operatorname{del}(7)$ (8.5), and with del $5(8.9$ years $)$ were younger compared with $\mathrm{CN}-\mathrm{AML}$ (9.5 years).

In the FAB subtype M4e, NRAS mutations were represented more frequently $(50 \%, 3$ of 6$)$ than they were in all other subtypes. In the M3, M5, M6 and M7 subtypes, no NRAS mutation was detected, making NRAS mutations highly underrepresented in these subtypes. In all other FAB subtypes, the distribution of NRAS mutations did not differ significantly from each other. A detailed distribution of NRAS mutations in the

Table 2. Clinical characteristics according to cytogenetic aberrations

\begin{tabular}{|c|c|c|c|}
\hline Cytogenetic & Frequency & Age(year) & WBCs $\left(\mathbf{x 1 0} \mathbf{3}^{\mathbf{3}} \boldsymbol{\mu \mathbf { L } )}\right.$ \\
\hline $\mathbf{N}=\mathbf{3 9}$ & N. (\%) & median & Median \\
\hline $\mathrm{t}(8 ; 21)$ & $6(15.4 \%)$ & 8.3 & 18 \\
\hline $\operatorname{inv}(16)$ & $6(15.4 \%)$ & 7.0 & 41 \\
\hline $\operatorname{del}(5)$ & $2(5.1 \%)$ & 8.9 & 34 \\
\hline $\operatorname{del}(7)$ & $1(2.6 \%)$ & 8.5 & 32 \\
\hline $\mathrm{CN}$ & $21(53.8 \%)$ & 9.5 & 38 \\
\hline Not done & $3(7.7 \%)$ & 9.0 & 29 \\
\hline
\end{tabular}

$\mathrm{CN}$ : cytogenetic normal 
Table 3. Frequency of NRAS mutation according to FAB and cytogenetics

\begin{tabular}{|c|c|c|}
\hline & $\boldsymbol{R A S}$ mutation & NO $\boldsymbol{R}$ AS mutation \\
Cytogenetic & $(\boldsymbol{n}=\mathbf{6})$ & $(\boldsymbol{n}=33)$ \\
\hline Good-risk group & & 5 \\
t(8;21) & 1 & 4 \\
t(inv16) & 2 & \\
\hline Poor-risk group & & 2 \\
del(5) & 0 & 1 \\
del(7) & 0 & 18 \\
\hline Normal group & & 3 \\
normal karyotype & 3 & 8 \\
Not done & 0 & 11 \\
\hline FAB & 1 & 2 \\
M1 & 1 & 4 \\
M2 & 0 & 3 \\
M3 & 1 & 2 \\
M4 & 3 & 1 \\
M4e & 0 & 2 \\
M5 & 0 & \\
M6 & & \\
M7 & & \\
\hline
\end{tabular}

respective FAB subtypes is presented in Table 3 .

Based on cytogenetic findings, the 39 patients were segregated into three groups: a good-risk group $(n=12)$ was defined by karyotype, $t(8 ; 21)$ or inv(16); a poorrisk group $(\mathrm{n}=3)$ by $\operatorname{del}(5)$ or $\operatorname{del}(7)$ and standard-risk group $(n=21)$ by normal karyotypes.

Based on the previous findings, we analyzed the influence of NRAS mutations on the prognosis of pediatric AML patients for whom clinical follow up data were available. Table 4 shows the clinical outcome in pediatric AML patients. In the total group, there was no difference with regard to $\mathrm{CR}$ rate (NRAS $^{\text {mutant }}, 66.7 \%$; NRAS ${ }^{\text {wild }}, 69.5 \% ; \mathrm{P}=0.43$ ). Relapse was significantly more frequent in the AML patients with NRAS gene mutations (NRAS ${ }^{\text {muant }}, 33.4$ $\%$; NRAS $^{\text {wild }}, 30.2 \% ; \mathrm{P}=0.26$ ).

At 3 years, the estimated OS was $30 \pm 15 \%$ in the

Table 4. NRAS mutation and clinical outcome

\begin{tabular}{|l|c|c|c|}
\hline Patients & $\begin{array}{c}\text { No RAS } \\
\text { mutation }\end{array}$ & $\begin{array}{c}\text { RAS } \\
\text { mutation }\end{array}$ & P \\
\hline All (n=39) & & & \\
\hline CR(\%) & 69.5 & 66.7 & 0.43 \\
\hline RR(\%) & 30.2 & 33.4 & 0.26 \\
\hline 3-year OS(\%) & 62 & 30 & 0.01 \\
\hline 3-year DFS(\%) & 59 & 35 & 0.007 \\
\hline
\end{tabular}

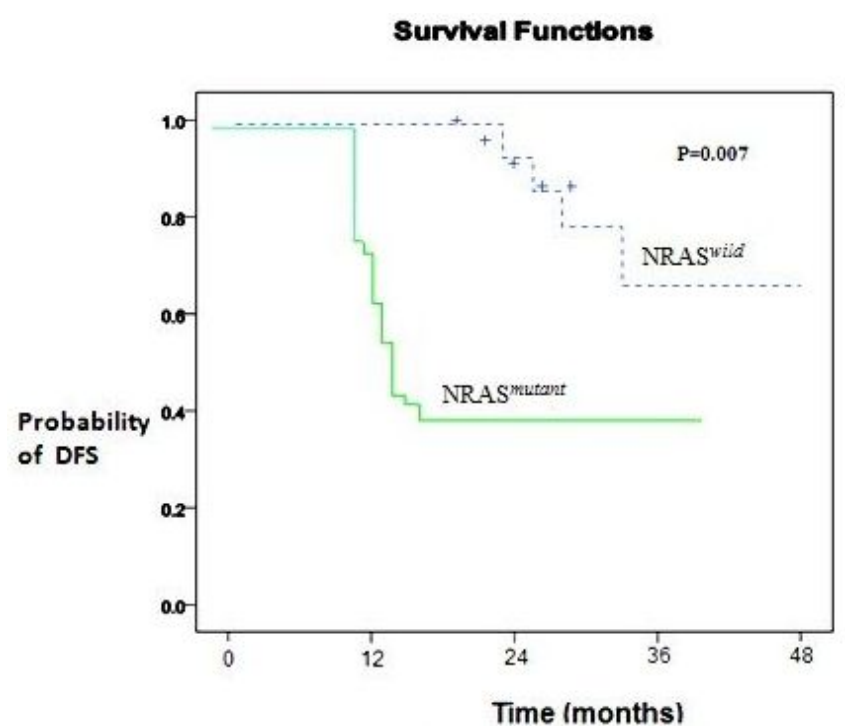

Figure 2. DFS in children with AML according to NRAS mutation.

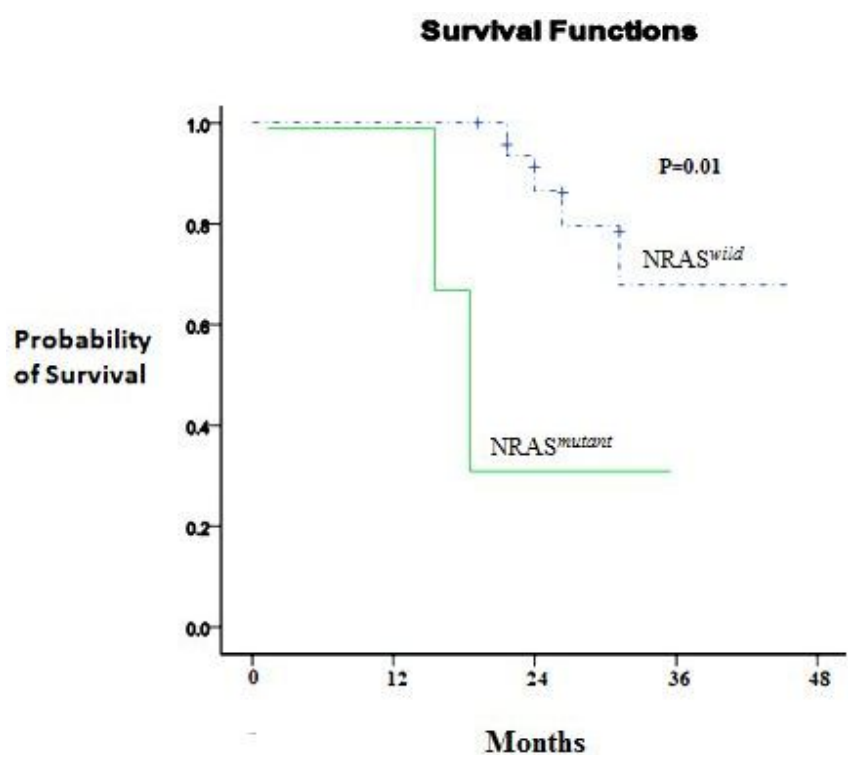

Figure 3. OS according to NRAS mutation.

presence of an NRAS mutation and $62 \pm 5 \%$ in its absence $(\mathrm{P}=0.01)$. Adverse prognosis associated with $\mathrm{N}$-ras mutations was observed in terms of 3 years DFS (NRAS $^{\text {mutant }} 35 \%$ vs NRAS ${ }^{\text {wild }} 59 \%, \mathrm{P}=0.007$ ), (Figure 2 and 3 ).

Univariate analysis showed that unfavorable prognostic factors for DFS were cytogenetic data $(\mathrm{P}=0.005)$ and NRAS mutation $(\mathrm{P}=0.002)$ (Table 5). Multivariate analysis showed NRAS was the strongest unfavorable factor (relative risk [RR], 3.6; $\mathrm{P}=0.007$ ), followed by cytogenetics $(\mathrm{P}=0.02)$.

Discussion. In recent years, a major focus of molecular cancer research has been the analysis of genes that may be causative in carcinogenesis (oncogenes). The clinical significance of RAS mutations has not been uniformly established. In the current study, we evaluated the clinical significance of NRAS mutations and investigated NRAS ${ }^{\text {mutant }}$ by genomic PCR method in 39 newly diagnosed pediatric AML cases. 
Table 5. Unvafourable prognostic factors for 3-year DFS in pediatric AML who achieved CR

\begin{tabular}{|c|c|c|c|c|}
\hline \multirow[t]{2}{*}{ Prognostic factors } & \multirow{2}{*}{$\frac{\text { Univariate }}{\mathrm{P} \text { value }}$} & \multicolumn{3}{|c|}{$\underline{\text { Multivariate }}$} \\
\hline & & $\underline{P \text { value }}$ & $\underline{\mathrm{RR}}$ & $\underline{95 \% \mathrm{CI}}$ \\
\hline \multicolumn{5}{|l|}{ Age (years) } \\
\hline 10 years or older & 0.3 & 0.2 & 2.1 & $1.2-6.5$ \\
\hline \multicolumn{5}{|l|}{ FAB } \\
\hline Other than M7 & 0.1 & 0.3 & 3.2 & $1.6-5.4$ \\
\hline \multicolumn{5}{|l|}{ *Cytogenetic } \\
\hline & 0.005 & 0.02 & 2.4 & $0.97-6.2$ \\
\hline \multicolumn{5}{|l|}{ NRAS mutation } \\
\hline & 0.002 & 0.007 & 3.6 & $1.5-8.5$ \\
\hline
\end{tabular}

Activated RAS mutations confer proliferative and survival signals. Mutations in the NRAS gene are frequent genetic aberrations in adult AML. ${ }^{19}$ However, there have been only a few studies on childhood AML. ${ }^{20}$ With different mutation-detection techniques used and heterogeneous patient populations studied, the reported incidence of NRAS ${ }^{\text {mutant }}$ in patients with childhood AML at presentation vary considerably; in our study $15.4 \%$ of pediatric AML patients (6/39) had NRAS $^{\text {mutant }}$, corresponding to the reported frequency by others. ${ }^{15,21}$ Primary analyses revealed a statistically significant association between peripheral and bone marrow blast counts and NRAS mutation $(\mathrm{P}=0.01, \mathrm{P}=0.04$ respectively), however no significant differences had been found between the two groups with respect to age, gender, platelet count and WBCs count. These findings are in agreement with those reported in literatures. ${ }^{10,13}$

The highest frequency $(33.3 \%)$ of NRAS mutations in our cohort (2/6) compared with the total cohort was detected in patients with inv(16). The high incidence of NRAS mutations in inv(16) in our study corresponded with most of the previously published studies reporting frequencies of $26 \%$ to $33 \%(22,23)$. 11q23/MLL aberrations are a frequent abnormality in pediatric AML. ${ }^{24,25,26}$ The frequency of 11q23/MLL-rearranged AML may have been underestimated because of low number of cases in the included study and because in our study as well as in other studies performed in the past, the cryptic MLL rearrangements may be not detected by conventional karyotyping. It is conceivable that the biological differences may lead to different treatment strategies for these age categories in the future. ${ }^{27}$ In our study, oldest children with AML were characterized by a high frequency of normal cytogenetic (53.8\%) but the very young in the included study are characterized by higher frequency of inv (16).

The prognosis of AML depends on factors such as age, initial leukocyte count, FAB classification, karyotype, immune phenotype, and response to remission-induction therapy. ${ }^{28,29}$ Our study showed that cytogenetic was unfavorable prognostic factor among AML patients by univariate analysis. This was in agreement with other study who found that cytogenetic data is thought to be the most important prognostic factor for AML. ${ }^{30}$

The prognostic significance of NRAS mutation in both adults and children remains disputed. Generally NRAS gene mutation is associated with tumor progression and was reported to be associated with poor prognosis in solid tumors and acute lymphoblastic leukemia (ALL). ${ }^{31,32}$ Published reports addressing the clinical significance of NRAS mutations in patients with acute myeloid leukemia are inconclusive. Whereas some studies demonstrated a beneficial clinical effect of NRAS mutations, ${ }^{33,34}$ others reached a different conclusion (e.g. lower CR) ${ }^{35}$ Other studies also did not that show that patients with NRAS mutations had significantly good outcomes. ${ }^{36,37}$

In this study, the presence of NRAS gene mutation was related to similar complete remission (CR) rates following induction chemotherapy compared with nonmutated patients $(66.7 \%$ vs. $69.5 \%, \mathrm{P}=0.43)$. Those in $\mathrm{CR}$ had a similar relapse rate regardless of the presence of NRAS mutations (RR $33.4 \%$ vs. $30.2 \%, \mathrm{P}=0.26$ ). However, the presence of NRAS mutations was associated with poor three years OS and DFS compared with wild type cases $(\mathrm{OS}, \mathrm{P}=0.01$; DFS, $\mathrm{P}=0.007)$. This discrepancy between these studies findings and our study may be explained by differences in the intensity of the chemotherapy protocols employed to treat this group of patients and the small number of our cases.

Conclusions. In addition to the evidence that activation of the RAS-signaling cascade contributes to the molecular pathogenesis of myeloproliferative disorders (38), NRAS mutation has adverse prognostic impact but further pediatric studies will be necessary to extend our knowledge and more precisely define the prognostic significance of NRAS mutations. This study also demonstrates the need to screen for specific translocation partners to allow appropriate treatment stratification like WT1 and FLT3.

\section{References:}

1. DG, Griffin JD. The roles of FLT3 in hematopoiesis and leukemia. Blood 2002; 100: 1532-1542. http://dx.doi.org/10.1182/blood-2002-02-0492 PMid:12176867

2. Ritter M, Kim TD, Lisske P, Thiede C, Schaich M, Neubauer A.
Prognostic significance of N-RAS and K-RAS mutations in 232 patients with acute myeloid leukemia. Haematologica 2004 89: 1397-1399. PMid: 15531466

3. Bachas C, Schuurhuis GJ, Hollink IH, Kwidama ZJ, Goemans 
BF, Zwaan CM, van den Heuvel-Eibrink MM, de Bont ES, Reinhardt D, Creutzig U, de Haas V, Assaraf YG, Kaspers GJ, Cloos J. High-frequency type I/II mutational shifts between diagnosis and relapse are associated with outcome in pediatric AML: implications for personalized medicine. Blood. 2010 Oct 14;116(15):2752-8. Epub 2010 http://dx.doi.org/10.1182/blood2010-03-276519 PMid:20592250

4. Meshinchi S, Woods WG, Stirewalt DL, Sweetser DA, Buckley JD, Tjoa TK, Bernstein ID, Radich JP.Prevalence and prognostic significance of Flt3 internal tandem duplication in pediatric acute myeloid leukemia. Blood. 2001 Jan 1;97(1):89-94 http://dx.doi.org/10.1182/blood.V97.1.89 PMid:11133746

5. Meshinchi S, Stirewalt DL, Alonzo TA, Zhang Q, Sweetser DA, Woods WG, Bernstein ID, Arceci RJ, Radich JP. Activating mutations of RTK/ras signal transduction pathway in pediatric acute myeloid leukemia. Blood. 2003 Aug 15;102(4):1474-9. http://dx.doi.org/10.1182/blood-2003-01-0137 PMid:12702504

6. Hollink IH, van den Heuvel-Eibrink MM, Zimmermann M, Balgobind BV, Arentsen-Peters ST, Alders M, Willasch A, Kaspers GJ, Trka J, Baruchel A, de Graaf SS, Creutzig U, Pieters R, Reinhardt D, Zwaan CM.Clinical relevance of Wilms tumor 1 gene mutations in childhood acute myeloid leukemia. Blood. 2009 Jun 4;113 (23):5951-60. http://dx.doi.org/10.1182/blood2008-09-177949 PMid:19171881

7. Ho PA, Zeng R, Alonzo TA, Gerbing RB, Miller KL, Pollard JA, Stirewalt DL, Heerema NA, Raimondi SC, Hirsch B, Franklin JL, Lange B, Meshinchi S.Prevalence and prognostic implications of WT1 mutations in pediatric acute myeloid leukemia (AML): a report from the Children's Oncology Group. $\begin{array}{llll}\text { Blood. } 2010 \quad \text { Aug } & 5 ; 116 & \text { (5):702-10, }\end{array}$ http://dx.doi.org/10.1182/blood-2010-02-268953

PMid:20413658 PMCid:2918327

8. Lubbert M, Mirro J Jr., Kitchingman G, et al. Prevalence of Nras mutations in children with myelodysplastic syndromes and acute myeloid leukemia. Oncogene. 1992;7:263-268. PMid: 1549347

9. Hirai H. Molecular Mechanisms of Myelodysplastic Syndrome. Jpn. J. Clin. Oncol 2003;33 (4): 153-160 http://dx.doi.org/10.1093/ijco/hyg037 PMid:12810828

10. Bowen D, Frew M, Hills R et al. RAS mutation in acute myeloid leukemia is associated with distinct cytogenetic subgroups but does not influence outcome in patients younger than 60 years. Blood 2005; 106: 2113-2119. http://dx.doi.org/10.1182/blood2005-03-0867 PMid:15951308

11. Goemans BF, Zwaan CM, Miller M, Zimmermann M, Harlow A, Meshinchi S, Loonen AH, Hählen K, Reinhardt D, Creutzig U, Kaspers GJ, Heinrich MC. Mutations in KIT and RAS are frequent events in pediatric core-binding factor acute myeloid leukemia. Leukemia. 2005 Sep;19(9):1536-42. http://dx.doi.org/10.1038/sj.leu.2403870 PMid:16015387

12. Beaupre DM, Kurzrock R. RAS and leukemia: from basic mechanisms to gene-directed therapy. J Clin Oncol. 1999;17:1071-1079. PMid:10071302

13. Illmer T, Thiede C, Fredersdorf A et al. Activation of the RAS pathway is predictive for a chemosensitive phenotype of acute myelogenous leukemia blasts. Clin Cancer Res 2005; 11: 3217 $3224 . \quad$ http://dx.doi.org/10.1158/1078-0432.CCR-04-2232 PMid: 15867216

14. Padua RA, West RR. Oncogene mutation and prognosis in the myelodysplastic syndromes. Br J Haematol 2000; 111:873-874. http://dx.doi.org/10.1046/j.1365-2141.2000.02472.x PMid:11122149

15. Paquette RL, Landaw EM, Pierre RV et al. N-Ras mutations are associated with poor prognosis and increased risk of leukemia in myelodysplastic syndrome. Blood 1993;82: 590-599 PMid:8329714

16. Lapillonne H, Liopis L, Auvrignon A, Renneville A, Labopin M, Mazingue F, Perot C, et al. Extensive mutational status of genes and clinical outcome in pediatric acute myeloid leukemia. Leukemia 2010; 205-209. http://dx.doi.org/10.1038/leu.2009.172 PMid:19759559

17. Radich JP, Kopecky KJ, Willman CL et al. N-Ras mutations in adult de novo acute myelogenous leukemia: prevalence and clinical significance. Blood 1990; 76:801-807. PMid:2200539

18. Mitelman F (ed). (1991). An international system for human cytogenetic nomenclature. Karger: Basel,1991.
19. Schaich M, Ritter M, Illmer T, et al. Mutations in ras protooncogenes are associated with lower mdrl gene expression in adult acute myeloid leukaemia. Br J Haematol 2001; 112: 300$307 . \quad$ http://dx.doi.org/10.1046/j.1365-2141.2001.02562.x PMid:11167822

20. Vogelstein B, Civin CI, Preisinger AC, et al. RAS gene mutations in childhood acute myeloid leukemia: a Pediatric Oncology Group study. Genes Chromosomes Cancer 1990; 2: 159-162. http://dx.doi.org/10.1002/gcc.2870020212

21. Liang DC, Shih LY, Fu JF, et al. K-ras mutations and N-ras mutations in childhood acute leukemias with or without mixedlineage leukemia gene rearrangements. Cancer 2006; 106: 950956. http://dx.doi.org/10.1002/cncr.21687 PMid:16404744

22. Valk PJM, Bowen DT, Frew ME, et al. Second hit mutations in the RTK/RAS signaling pathway in acute myeloid leukemia with inv(16) [abstract]. Haematologica 2004; 89:106. PMid:14754614

23. Beghini A, Peterlongo P, Ripamonti CB, et al. C-kit mutation in core binding factor leukemias. Blood 2000; 95:726-727. PMid:10660321

24. Harrison CJ, Hills RK, Moorman AV, Grimwade DJ, Hann I, Webb DK, Wheatley K, de Graaf SS, van den Berg E, Burnett AK, Gibson BE. Cytogenetics of childhood acute myeloid leukemia: United Kingdom Medical Research Council Treatment trials AML 10 and 12. J Clin Oncol. 2010 Jun 1;28(16):2674-81. Epub $\quad 2010 \quad$ http://dx.doi.org/10.1200/JCO.2009.24.8997 PMid:20439644

25. von Neuhoff C, Reinhardt D, Sander A, Zimmermann M, Bradtke J, Betts DR, Zemanova Z, Stary J, Bourquin JP, Haas OA, Dworzak MN, Creutzig U. Prognostic impact of specific chromosomal aberrations in a large group of pediatric patients with acute myeloid leukemia treated uniformly according to trial AML-BFM 98. J Clin Oncol. 2010 Jun 1;28(16):2682-9. http://dx.doi.org/10.1200/JCO.2009.25.6321 PMid:20439630

26. Bachas C, Schuurhuis GJ, Hollink IH, Kwidama ZJ, Goemans BF, Zwaan CM, van den Heuvel-Eibrink MM, de Bont ES, Reinhardt D, Creutzig U, de Haas V, Assaraf YG, Kaspers GJ, Cloos J. High-frequency type I/II mutational shifts between diagnosis and relapse are associated with outcome in pediatric AML: implications for personalized medicine. Blood. 2010 Oct 14;116(15):2752-8. http://dx.doi.org/10.1182/blood-2010-03276519 PMid:20592250

27. Balgobind BV, Hollink IH, Arentsen-Peters ST, Zimmermann M, Harbott J, Beverloo B, von Bergh AR, Cloos J, Kaspers GJ, de Haas V, Zemanova Z, Stary J, Cayuela JM, Baruchel A, Creutzig U, Reinhardt D, Pieters R, Zwaan CM, van den HeuvelEibrink MM.Integrative analysis of type-I and type-II aberrations underscores the genetic heterogeneity of pediatric acute myeloid $\begin{array}{lll}\text { leukemia. Haematologica. 2011, 96(10):1478-1487 } & \end{array}$ http://dx.doi.org/10.3324/haematol.2010.038976 PMid:21791472 PMCid:3186309

28. Kobayashi T, Miyawaki S, Tanimoto M, Kuriyama K, et al Randomized trials between behenoyl cytarabine and cytarabine in combination induction and consolidation therapy, and with or without ubenimex after maintenance/ intensification therapy in adult acute myeloid leukemia. The Japan Leukemia Study Group. J Clin Oncol 1996; 14:204. PMid:8558199

29. Miyawaki S, Tanimoto M, Kobayashi T, Minami S, et al Randomized study of individualized induction therapy with or without etoposide in adult acute myeloid leukemia (except for M3) (JALSG-AML92 study) and analysis of prognostic factors. Blood 1997; 90:503a.

30. Mro'zek K, Heinonen K, de la Chapelle A, Bloomfield CD: Clinical significance of cytogenetics in acute myeloid leukemia. Semin Oncol 1997; 24:17. PMid:9045301

31. Slebos RJ, Kibbelaar RE, Dalesio O, Kooistra A, Stam J, Meijer CJ, Wagenaar SS, Vanderschueren RG, van Zandwijk N, Mooi WJ, Bos JL, Rodenhuis S: K-RAS oncogene activation as a prognostic marker in adenocarcinoma of the lung. N Engl J Med 1990; $\quad 323 ; 9$ : 561-565. http://dx.doi.org/10.1056/NEJM199008303230902 PMid:2199829

32. Lübbert M, Mirro J Jr, Miller $\mathrm{CW}$, Kahan $\mathrm{J}$, Issac $\mathrm{G}$, Kitchingman G, Mertelsmann R, Herrmann F, McCormick F, Koeffler HP: N-Ras gene point mutations in childhood acute lymphocytic leukemia correlate with a poor prognosis. Blood 1990; 75:1163-1169. PMid:2407301 
33. Neubauer A, Dodge RK, George SL, Davey FR, Silver RT, Schiffer CA, et al. Prognostic importance of mutations in the ras proto-oncogenes in de novo acute myeloid leukemia. Blood 1994;83:1603-11. PMid:8123851

34. Coghlan DW, Morley AA, Matthews JP, Bishop JF. The incidence and prognostic significance of mutations in codon 13 of the Nras gene in acute myeloid leukemia. Leukemia 1994; :1682-7. PMid:7934163

35. Kiyoi H, Naoe T, Nakano Y, Yokota S, Minami S, Miyawaki S, et al. Prognostic implication of FLT3 and N-RAS gene mutations in acute myeloid leukemia. Blood 1999;93:3074-80. PMid:10216104

36. De Melo MB, Lorand-Metze I, Lima CS, Saad ST, Costa FF N- ras gene point mutations in Brazilian acute myelogenous leukemia patients correlate with a poor prognosis. Leuk Lymphoma. 1997;24 :309-17. PMid:9156660

37. Stirewalt DL, Kopecky KJ, Meshinchi S, Appelbaum FR, Slovak ML, Willman CL, et al. FLT3, RAS, and TP53 mutations in elderly patients with acute myeloid leukemia. Blood 2001;97:3589- 95. http://dx.doi.org/10.1182/blood.V97.11.3589 PMid:11369655

38. Chan IT, Kutok JL, Williams IR, Cohen S, Kelly L, Shigematsu $\mathrm{H}$, et al. Conditional expression of oncogenic K-ras from its endogenous promoter induces a myeloproliferative disease. J Clin Invest 2004;113:528-38. PMid:14966562 PMCid:33826 